\title{
Finding a happy medium
}

Be careful what you think out loud...

\section{John Gilbey}

The lab meeting droned on through the blazing, fetid April afternoon. Air conditioning is for systems, not people, according to Tim - my department head - whose plodding tones mapped out a tale of woe and crisis.

"So that wraps it up for finance - it ain't good. But before you rush off", he raised his voice over the scrape of chairs, "I've got the latest hot news from the faculty board - so sit down. Thanks".

Pushing aside his notes, Tim laid his hands flat on the smeared glass of the table. "I don't need to remind you how much trouble the university has had with fraud over the past few years. I'm sure you all remember how hairy things got when Fred's team got busted for running two information systems - the real one and the one the journal referees got to see. And don't think I've forgotten how jealous some of you were - until they got rumbled..."

"Well, our beloved University of Rural England has been quietly rebuilding Internal Audit in order to, and I quote, bring a new level of assurance to our sponsors regarding scientific probity - through the innovative use of A-Psi technology."

"What the hell is A-Psi?" demanded the bald hippybeside me. Tim looked amused but embarrassed.

"Apparently it stands for 'Assisted Psychic.' The new auditor is a certified clairvoyante calibrated to international standards - and she's a biologist too, so don't think you'll be able to doubletalk your way out. 'Assisted' means they use some new gizmo to amplify and record the data stream while she reads your mind" Tim looked slowly round the table, "I can't say I envy her - because you lot are top of the list."

The meeting dissolved in uproar as Tim's MeetingSec gave up the unequal struggle to transcribe 12 streams of screamed invective.

By Monday, people had simmered down a bit, but how should we handle the audit? I asked Tim for advice. "Just one thing," he muttered, "try not to get her angry."

"Why not? What have you heard?"

Tim shook his head slowly. "Just don't, that's all."

I was pondering this when the audit team arrived in my office. The lead auditor was tall, with long auburn hair and green eyes so piercing they looked like fakes. Somehow, I knew they weren't. Her companion was male, obese, sweaty and clutching a data recorder. She introduced him as Keith. I didn't take to Keith. Her name was Claire - which I tried hard not to find amusing, given Tim's advice.

Over her black business suit Claire wore a pendant set with a stone that looked something like opal - patterns of light flashed from it as she moved. Her hand reached up and

touched the jewel. "The amulet is a dynamic

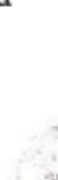

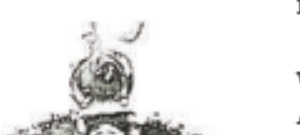

(1)

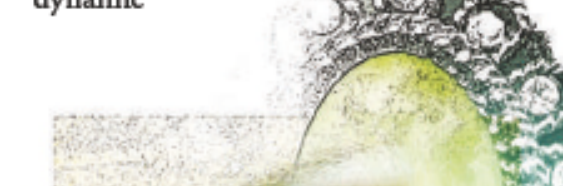

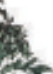
he pointed out, "they think you're hiding something. They want you back on Monday - just go down there and give them whatever they ask for."

After a weekend of stomachchurning uncertainty, I presented myself at the appointed door in the Registry building. I knocked: it opened. Gently filtered light suffused the room. Claire was sitting on a sofa, holding the amulet. She motioned me to sit down. An interactive hologram of a ginger cat turned at my approach, then went back to sleep. Keith, thankfully, was nowhere to be seen.

The question came again - "Is there anything you want to tell me?" I tried, without success, to stem the rush of thoughts. Scenes of unquenchable desire - Claire, myself and our future together - burst out like water from a broken dam, to my utter horror and bewilderment. I began to stutter an apology, but she silenced me with a single flash of green.

nanotech array," she explained. "It helps me see the way you react to things."

"You mean to read my mind?" I blurted out.

${ }^{\alpha} \mathrm{No}$ ! Why does everyone think that? I can only see what you choose to show me, only that! ${ }^{x}$ The colour rose in Claire's cheeks, and I waited for a further explosion - but she composed herself and continued in measured tones.

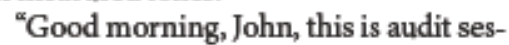
sion URE/BIO/009, 23 April 2026. My terms of reference for this audit are as follows..." Keith's recorder began to hum quietly.

Two hours later things were winding up. “OK, John, we’ve looked at data management and the document system. I am happy with the sample schedule and we've
She gently placed $\mathrm{my}$ hand over the amulet. It felt like the first touch of morphine - like having my brain rinsed in cool spring water. Then came a rush of images from Claire, almost a mirror of my own but deeper, more powerful and dramatically more graphic - along with a pang of loneliness.

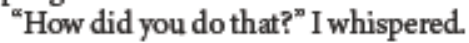

Claire smiled and closed her hand over mine, pressing the amulet into my palm. 'Let's just say it's an undocumented feature..." The cat stretched languidly and began to purr.

John Gilbey is a hopeless romantic, or just hopeless - depending on your point of view. He is keen to point out that he writes in a private capacity. 